\title{
Plasma cell Leukaemia in a young male-A rare case report
}

\section{Menka Kapil ${ }^{1,}$, , Aditi Mittal ${ }^{2}$, Ankita Saini ${ }^{3}$, Anisha Jaipuria ${ }^{4}$}

Consultant Department of Pathology, SR Kalla Hospital and Research Centre, Jaipur, India

*Corresponding Author: Menka Kapil, Consultant Department of Pathology, SR Kalla Hospital and Research Centre, Jaipur, India

Received date: 12 May 2021; Accepted date: 21 May 2021; Published date: 30 May 2021

Citation: Kapil M, Mittal A, Saini A, Jaipuria A. Plasma cell Leukaemia in a young male-A rare case report. J Med Case Rep Case Series 2(6): https://doi.org/10.38207/jmcrcs20210059

Copyright: (C) 2021 Menka Kapil. This is an open-access article distributed under the terms of the Creative Commons Attribution License, which permits unrestricted use, distribution, and reproduction in any medium, provided the original author and source are credited.

\begin{abstract}
Plasma cell leukaemia (PCL) is a rare neoplasm and is the most aggressive form in the spectrum of multiple myeloma. It is classified as primary or de novo and secondary in patient of multiple myeloma. Organomegaly and bleeding tendency are common in primary PCL and less in secondary as in our case. Osteolytic lesions are seen less frequently in Plasma cell leukaemia. The diagnosis is made by an emphasis on the morphological appearances and confirmation by serum electrophoresis and immunophenotyping. In our case the presence of plasma cells in peripheral blood was more than $20 \%$ in young patient at the age of 34 years which is very rare and is further confirmed by immunophenotyping.
\end{abstract}

Keywords: Plasma cell leukaemia, anaemia, multiple myeloma

\section{Introduction}

Plasma cell leukaemia is a rare plasma cell dyscrasia and is the most aggressive form in the spectrum of multiple myeloma. Kyle and Noel first defined it as the presence of plasma cells more than $20 \%$ of the differential white count in the peripheral blood or peripheral blood shows the presence of absolute plasma cell count more than $2.0 \mathrm{x}$ 109/L. [1] Plasma cell leukaemia is classified as "primary" occurring de novo or "secondary" occurring in patients with Multiple myeloma. Primary Plasma cell leukaemia has an aggressive course and progresses rapidly without therapy. The prognosis is often poor with mortality within the first month is as high as $15 \%$. As the incidence of Plasma cell leukaemia is low therefore knowledge about clinic

\section{Case Report}

A 34-year-old male with complaints of general malaise, rashes, fatigue, and fever in the last month was admitted to our hospital. He had no history and family history of diabetes and hypertension.He was a non-smoker and non- pathological features and response to current therapy is still less. Anaemia, elevated serum lactate dehydrogenase, increased beta- 2 microglobulin, hypercalcaemia, hypalbuminaemia, and renal impairment are commonly seen in primary plasma cell leukaemia [2] Osteolytic lesions are comparatively less commonly seen in primary plasma cell leukaemia as compared to multiple myeloma [3]. It is seen that even lower levels of circulating clonal plasma cells in peripheral blood below the World Health Organization's threshold for defining plasma cell leukaemia had a poor prognosis comparable with that of the strictly defined plasma cell leukaemia. [4,5] Therefore definition of Plasma cell leukaemia is still under debate.

alcoholic. On examination, hepatosplenomegaly, palpable purpura, and plaques were present mainly on both lower limbs.

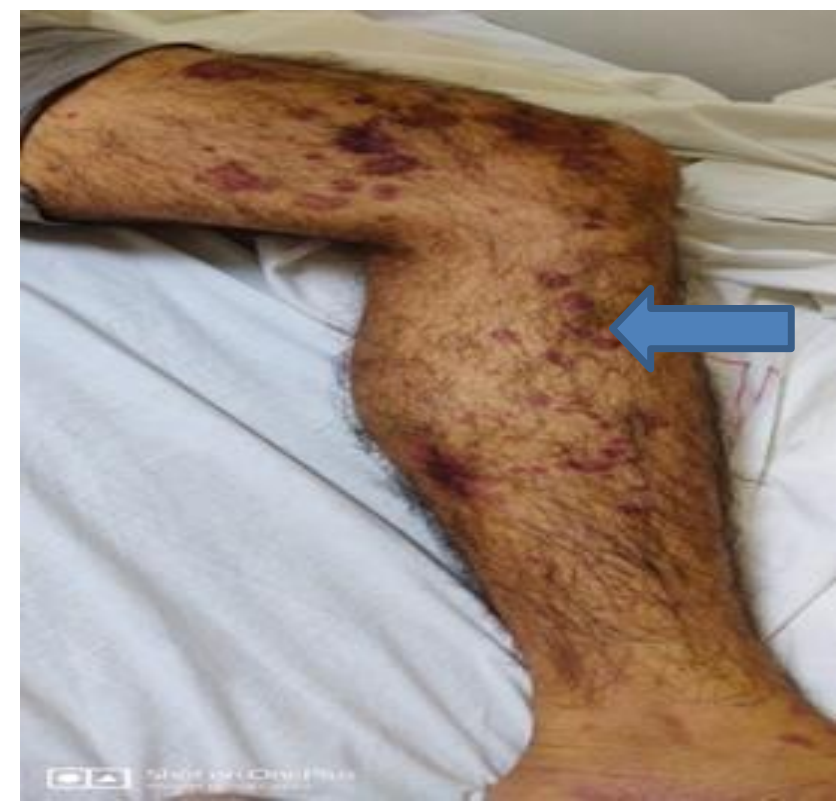

Figure 1: Purpura at lower limb as shown by arrow. 
The hemogram showed normochromic normocytic anaemia of $6.9 \mathrm{~g} / \mathrm{dL}$, leucocytosis of $96.58 \times 10^{9} / \mathrm{L}$ and thrombocytopenia of $76 \times 10^{9} / \mathrm{L}$, with finding of $69 \%$ cells that are plasma cells with eccentric nucleus, sieve like chromatin, basophilic cytoplasm as shown in figure 2.

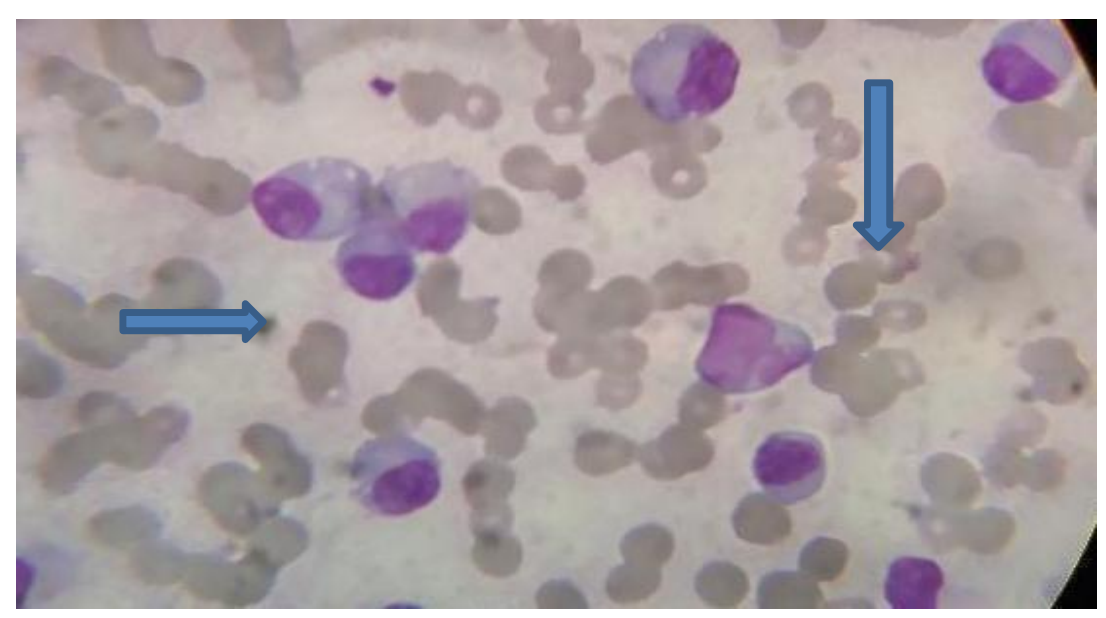

Figure-2 Peripheral blood showed rouleaux formation long arrow and plasma cell with small arrow.

Other laboratory parameters were INR-1.45 sec, serum creatinine 1.6 $\mathrm{mg} / \mathrm{dl}$, serum calcium- $10.2 \mathrm{mg} / \mathrm{dl}$, total bilirubin was $0.5 \mathrm{mg} / \mathrm{dl}$, direct bilirubin- $0.2 \mathrm{mg} / \mathrm{dl}$, serum protein- $9.3 \mathrm{gm} / \mathrm{dl}$, albumin- 4.01 gm/dl, globulin- 5.29 g/dL. Lactate dehydrogenase- 855 U/L, Beta-2 microglobulin-7 mg/L, Antinuclear antibody was not detected. Hepatitis B surface antigen and Anti-HIV-1,2 was negative. Direct and indirect coombs test were negative.

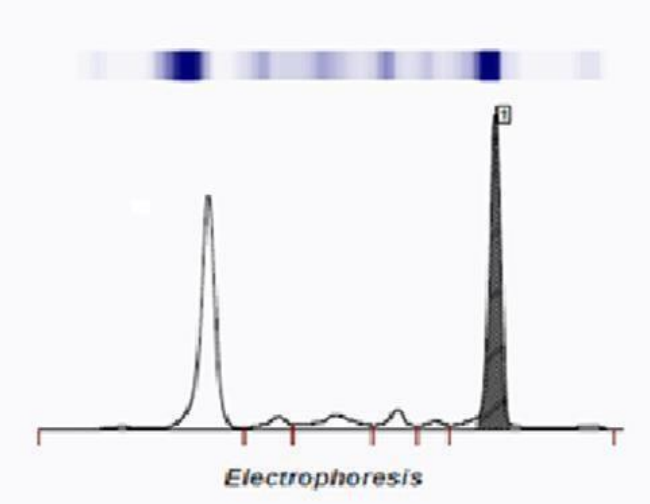

Figure 3 - Schematic representation of protein electrophoresis shows the fractions of albumin, globulins as alpha-1 ( $\alpha 1)$, alpha-2 ( $\alpha 2)$, beta $(\beta)$, gamma $(\gamma)$, and monoclonal spike in gamma region.

Bone marrow aspiration was performed with 72 per cent of cells being plasma cells and bone marrow biopsy showed hypercellular marrow with decreased erythropoietic and myelopoietic cells. The majority of the marrow spaces were replaced by plasma cells.

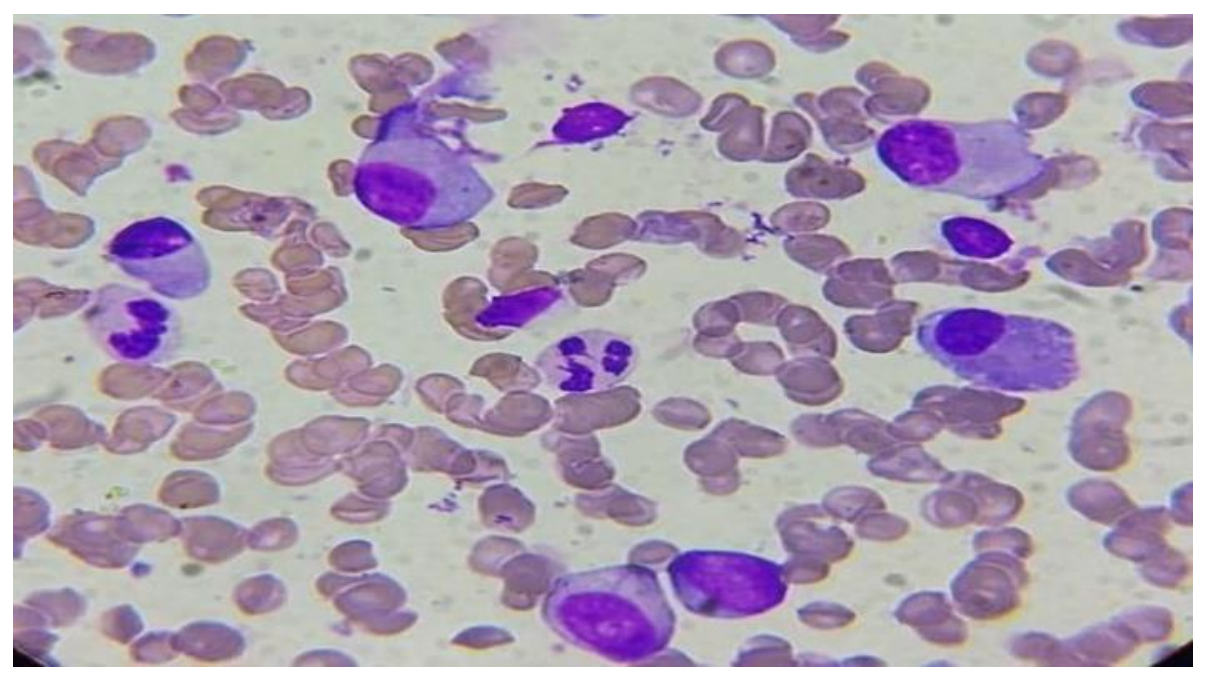

Figure-4, Bone marrow aspiration shows plasma cell marked with arrow.

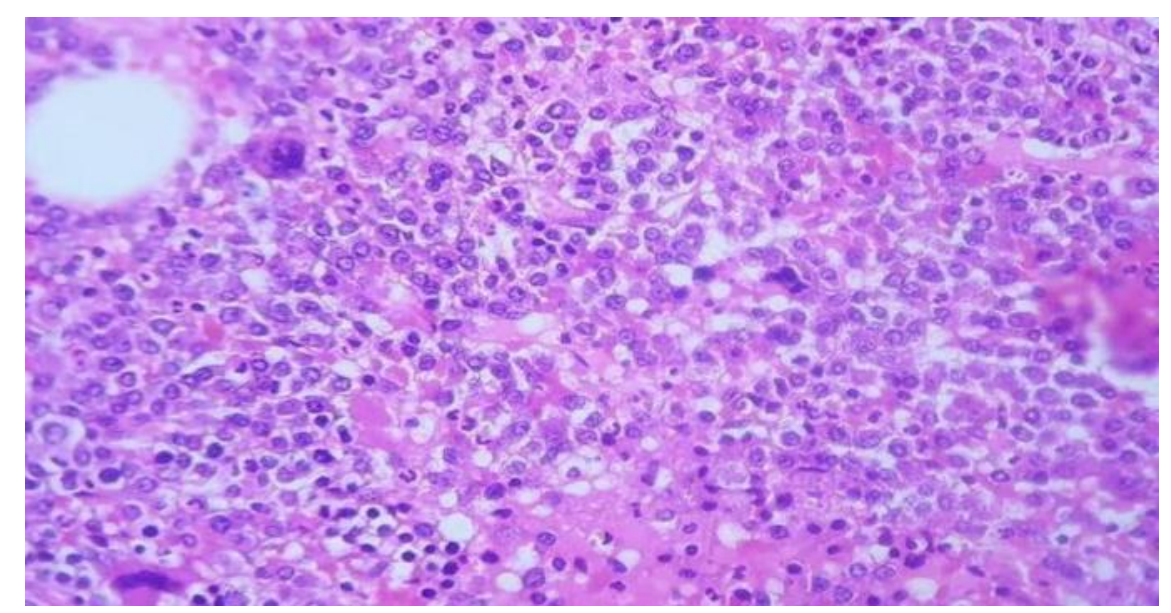

Figure 5, Hypercellular bone marrow biopsy showed increased plasma cells shown by arrow with decreased normal hemopoietic element. 
The peripheral blood immunophenotyping by flow cytometric analysis revealed a distinct population (79\% of total events) which was bright CD38 positive with negative CD45 and low SSC. The cells show cytoplasmic kappa light chain restriction and are positive for CD56, CD81, CD138 and CD38. Few atypical cells also showed aberrant expression of CD 117 and CD13. They were negative for CD19, CD20, CD27, CD200 markers as

\section{Discussion}

The median age of diagnosis of Primary Plasma cell leukaemia is 55 years which is a decade younger in comparison with multiple myeloma [6], however, our patient was young at 35 years of age. The diagnosis of plasma cell leukaemia is based upon the evaluation of peripheral blood smear, bone marrow aspirate and biopsy, protein electrophoresis and flow cytometric evaluation. The diagnosis of Plasma cell leukaemia is confirmed when a monoclonal population of plasma cells are present in the peripheral blood with an absolute plasma cell count exceeding $2000 / \mu \mathrm{L}$ and $20 \%$ of the peripheral blood white cells.

It is a very uncommon and aggressive form of monoclonal gammopathy which is characterized by poor prognosis and rapidly fatal outcomes. The outcome is thought to be poor because of the absence of effective treatment for this condition [7].

Plasma cell leukaemia is classified as "primary" occurring de novo or "secondary" occurring in patients with multiple myeloma. There are few differences between these two haematological disorders which must be kept in mind during diagnosis and treatment of the disease. Patients with plasma cell leukaemia are usually younger aged 50-59 years. In plasma cell leukaemia plasma cells, circulate in peripheral blood and lead to extramedullary spread involving the liver, spleen, lymph nodes, pleura, peritoneum, and less often the bone, resulting in lytic lesions that are more in multiple myeloma.

He was treated with weekly bortezomib, Adriamycin, dexamethasone along lenalidomide. Adriamycin was given for 1 cycle only. The skin lesions gradually flattened and then faded with treatment. After 7 cycles of VRD, the M spike decreased to 0.48 . Then he was started on KPD for 3 cycles and attained complete remission. He underwent autologous stem cell transplant six months after the treatment and is

\section{Conclusion}

Plasma cell leukaemia is the most aggressive variant of monoclonal gammopathy and is a rare form of clonal plasma cell dyscrasia. Even rare at a younger age as seen in our case. Plasma cell leukaemia and Multiple analysed. Of the remaining cells, $8 \%$ are granular myeloid, and $10 \%$ are lymphoid. These findings are suggestive of plasma cell leukaemia with 79 $\%$ cells with plasma cell immunophenotype with aberrant expression of CD117 and CD13. The FISH panel was negative for 1q21 gain, del 13q, $t$ $(11 ; 14), \mathrm{t}(4 ; 14), \mathrm{t}(14 ; 1)$.

in Complete remission since then. Since the prognosis is very poor, the use of combination chemotherapy followed by autologous/allogeneic stem cell transplantation is required to improve survival.

The extramedullary spread is explained by negative CD56, a cell adhesion molecule that anchors plasma cells to the bone marrow stroma in contrast to Multiple myeloma, where most of the plasma cell population are found in bone marrow [8]. Hypercalcemia, low platelet count, and destruction of erythrocytes are found in both diseases, but it is often seen in Plasma cell leukaemia as compared to multiple myeloma. Most plasma cell leukaemia patients have abnormal karyotypes. Plasma cell markers, which can be identified on immunophenotyping, include CD38 and CD138, as seen in our patient. Flow cytometry should be performed on peripheral blood to confirm the presence of plasma cells that typically have immunophenotypes of CD138+, CD38+, CD19-, and CD45+/-.

Patients having primary plasma cell leukaemia must undergo a detailed history and physical examination. A comprehensive laboratory evaluation of blood should be performed, including a complete blood count with differential, peripheral blood smear, urea and creatinine levels, bilirubin, lactate dehydrogenase, uric acid, $\beta 2$ macroglobulin, albumin, serum protein electrophoresis, and serumfree light chain analysis. Chest X-ray along with whole-body imaging with either MRI or CT should be performed to look for metastasis. Finally, it is imperious to perform bone marrow aspiration and biopsy to assess morphology, proliferation rate, immunophenotyping, and cytogenetic analysis by FISH [9]

myeloma are distinct clinic-pathologic entities with different treatment options and most importantly, different prognoses. Therefore, early diagnosis and treatment is a must.

\section{Financial Disclosure: Nil.}

Informed Consent: The authors declare that it has been signed by the patient involved in the case including images. 


\section{References}

1. Noel P, Kyle RA (1987) Plasma cell leukaemia: an evaluation of response to therapy. Am J Med. 83(6): 1062-1068.

2. García-Sanz R, Orfão A, González M, Tabernero MD, Bladé J, et al. (1999) Primary plasma cell leukaemia: clinical, immunophenotypic, DNA ploidy, and cytogenetic characteristics. Blood 93(3): 1032-7.

3. Bladé J, Kyle RA (1999) Nonsecretory myeloma, immunoglobulin D myeloma, and plasma cell leukaemia. Hematol Oncol Clin North Am. 13(6): 1259-72.

4. Shah RA, Mohite S, Baladandayuthapani V, Thomas SK, Weber DM, et al. (2013) Circulating plasma cells by routine complete blood count identify patients with similar outcome as plasma cell leukaemia. Blood. 122(21): 5356.

5. Granell M, Calvo X, Garcia-Guiñón A, Escoda L, Abella E, et al (2016) Prognostic impact of circulating plasma cells in patients with multiple myeloma: implications for plasma cell leukaemia definition. Haematologica. 102(6): 1099-1104.

6. Gonsalves WI, Rajkumar SV, Go RS, Dispenzieri A, Gupta V, et al. (2014) Trends in survival of patients with primary plasma cell leukaemia: a population-based analysis. Blood 124(6): 907-12.

7. International Myeloma Working Group. Criteria for the classification of monoclonal gammopathies, multiple myeloma and related disorders: a report of the International Myeloma Working Group. Br J Haematol. 2003; 121(5): 749-757.

8. Bladé J, Kyle RA (1999) Nonsecretory myeloma, immunoglobulin D myeloma, and plasma cell leukaemia. Hematol Oncol Clin North Am. 13(6): 1259-1272

9. Fernández de Larrea C, Kyle RA, Durie BG, Ludwig H, Usmani S, et al. (2013) Plasma cell leukaemia: consensus statement on diagnostic requirements, response criteria and treatment recommendations by the International Myeloma Working Group. Leukemia. 27(4): 780-791. 